\title{
Resistensi Ikan Gurami (Osphorenemus gouramy) Terhadap Infeksi Aeromonas hydrophila Setelah Perendaman Ekstrak Air Panas Spirulina plantesis
}

\author{
Lina Wafia Asmi*1, Woro Hastuti Satyantani, Sri Subekti \\ Prodi S2 Bioteknologi Perikanan dan Kelautan, Sekolah Pascasarjana, Universitas \\ Airlangga, Surabaya \\ e-mail: lina.wafia13@gmail.com*1
}

\begin{abstract}
Abstrak
Gurami telah umum dibudidayakan dan menjadi andalan sebagai salah satu sumber protein hewani, namun masih menghadapi kendala dalam hal budidaya yaitu pertumbuhan yang lambat dan ketahanan hidup yang rendah. Salah satu penyebabnya adalah serangan penyakit oleh bakteri Aeromonas hydrophila. Spirulina platensis merupakan mikroalga yang dapat digunakan sebagai immunostimulan. Lipopolisacarida (LPS) yang terkandung pada Spirulina platensis dapat memperbaiki system imunitas pada ikan gurami. Penelitian ini bertujuan untuk mengetahui resistensi ikan gurami (Osphorenemus gouramy) terhadap infeksi Aeromonas hydrophila setelah perendaman ekstrak air panas Spirulina platensis. Rancangan penelitian yang digunakan adalah Analisis Varian dilanjutkan dengan Duncan, dengan menggunakan 5 perlakuan yaitu $\mathrm{K}^{-}$(tanpa perendaman ekstrak S.platensis dan tanpa diinfeksi A.hydrophila), $\mathrm{K}^{+}$(tanpa perendaman ekstrak S.platensis dan diinfeksi dengan A.hydrophila), A (perendaman ekstrak S.platensis 15 ppm dan diinfeksi dengan A.hydrophila), B (perendaman ekstrak S.platensis 30 ppm dan diinfeksi dengan A.hydrophila), dan C (perendaman ekstrak S.platensis 60 ppm dan diinfeksi dengan A.hydrophila). Kepadatan A.hydrophila yang diinfeksi terhadap ikan gurami adalah $10^{5} \mathrm{cfu} / \mathrm{mL}$ yang disuntikkan secara intra peritoneal $0.1 \mathrm{~mL} / \mathrm{ekor}$. Perendaman ekstrak S.platensis dilakukan pada hari ke-1 dan ke-7, sedangkan infeksi A.hydrophila dilakukan pada hari ke-15. Parameter yang diamati adalah kelulus hidupan, total leukosit, aktivitas lisozim, dan histopatologi hati. Pengamatan dilakukan pada hari ke $-7,-14,-25$, sedangkan untuk histopatologi hati hanya dilakukan pada hari ke-25. Hasil penelitian menunjukkan bahwa perendaman ekstrak air panas Spirulina platensis dapat meningkatkan resistensi ikan gurami terhadap A.hydrophila dibanding dengan control $(\mathrm{p}<0.05)$. Resistensi terbaik ikan gurami terhadap A.hydrophila diperoleh dari ikan gurami dengan perendaman $30 \mathrm{ppm}$ dengan kelulus hidupan $77 \%$, total leukosit $60,32 \times 10^{4}$ $\mathrm{sel} / \mathrm{mm}^{3}$, aktivitas lisozim 1,33. Pengukuran kualitas air selama penelitian menunjukkan suhu air berkisar antara $28-28,5^{\circ} \mathrm{C}, \mathrm{pH}$ berkisar antara 7,3-7,5. Amonia berkisar antara 0,5 - 0,52 mg/l, sedangkan oksigen terlarut berkisar antara $5,04-5,41 \mathrm{mg} / \mathrm{L}$.
\end{abstract}

Kata kunci : Osphorenemus gouramy, Spirulina platensis, Aeromonas hydrophila

\section{Abstract}

Gouramy has been generally cultivated and being one of mainstay animal protein source, but still faced some obstacles in cultivated that is low growth and low survival rate. One of the reason is diseases by Aeromonas hydrophila bacteria. Spirulina platensis is microalgae which is used as immunostimulant. Lipopolisacarida (LPS) which is in Spirulina platensis can improve immunity system in gouramy. The purpose of this research is to understand gouramy (Osphorenemus gouramy) resistance towards Aeromonas hydrophila infection after submersion of Spirulina plantesis hot water extract. Research design which is used is Variance Analysis 
continued with Duncan, by used 5 treatment that is $K^{-}$(without submersion of S.platensis exctract and without A.hydrophila infected), $K^{+}$(without submersion of S.platensis exctract and with A.hydrophila infected), A (with submersion of S.platensis 15 ppm exctract and with A.hydrophila infected), B (with submersion of S.platensis 30 ppm exctract and with A.hydrophila infected) and $C$ (with submersion of S.platensis 60 ppm exctract and with A.hydrophila infected). A.hydrophila density which is infected towards gouramy is $10^{5} \mathrm{cfu} / \mathrm{mL}$ injected by intra peritoneal $0.1 \mathrm{~mL} / \mathrm{fish}$. The submersion done at $1^{\text {st }}$ day and $7^{\text {th }}$ day, while A.hydrophila infection done at $15^{\text {th }}$ day. The observed parameter is survival rate, total of leucocyte, lisozyme activity, and liver histopatology. Observation done at $7^{\text {th }}$ day, $14^{\text {th }}$ day and $25^{\text {th }}$ day, while the liver hitopatology only done at $25^{\text {th }}$ day. The result show that submersion of Spirulina plantesis hot water extract can improved gouramy resistance towards A.hydrophila if compared by control $(p<0.05)$. The best resistance result of gouramy towards A.hydrophila is from gouramy treatment with submersion $30 \mathrm{ppm}$ which show result survival rate 77\%, total of leucocyte show result $60,32 \times 10^{4} \mathrm{sel} / \mathrm{mm}^{3}$, lisozyme activity show result 1,33. Water quality measurement during research shows water temperature about 7,3-7,5, ammonia about 0,5 - 0,52 $\mathrm{mg} / \mathrm{l}$, while dissolved oxygen about 5,04 $5,41 \mathrm{mg} / \mathrm{L}$.

Keyword: Osphorenemus gouramy, Spirulina platensis, Aeromonas hydrophila

\section{PENDAHULUAN}

Ikan gurami (Osphronemus gouramy) telah umum dibudidayakan dan menjadi andalan sebagai salah satu sumber protein hewani. Kawasan pengembangan budidaya ikan gurami juga sudah terbentuk di beberapa daerah, seperti di Jawa Barat (Bogor, Tasikmalaya, Ciamis, Garut), Jawa Tengah (Cilacap, Banyumas, Banjarnegara, Purbalingga), Yogyakarta (Kulonprogo, Bantul, Sleman), Jawa Timur (Tulungagung, Blitar, Lumajang), Sumatra Barat dan Riau. (KKP, 2015). Kementerian Perikanan dan Kelautan (2015) menjabarkan jumlah produksi ikan gurami pada tahun 2010 mencapai 55.331 ton dan terus meningkat sampai tahun 2012 dengan jumlah produksi 82.794 ton, sedangkan jika dilihat dari nilai produksi menunjukkan ikan gurami merupakan produksi perikanan budidaya kolam dengan nilai tertinggi dibanding dengan ikan budidaya kolam lainnya, yakni pada tahun 2011 mencapai Rp. 137.292.865.980,- . Walaupun ikan gurami sudah lama dibudidayakan secara komersial namun masih menghadapi kendala dalam hal budidaya yaitu pertumbuhan yang lambat dan ketahanan hidup yang rendah. Salah satu penyebabnya adalah serangan penyakit oleh bakteri Aeromonas hydrophila (Tanjung dkk.,2011).

Dalam kondisi normal, A. hydrophila biasa ditemukan pada lingkungan perairan tawar dan merupakan penghuni saluran gastrointestinal. Penyakit yang disebabkan oleh bakteri ini terutama menyerang ikan air tawar seperti ikan Gurami, Lele, ikan Mas dan spesies ikan tropis lainnya termasuk ikan hias. Bakteri A. hydrophila merupakan penyebab utama aeromonas (Motile Aeromonas Septichaemia, MAS) atau Hemorrhagic Septichaemia pada berbagai hewan air, terutama ikan air tawar (Austin dan Adams, 2007). Penyakit MAS yang disebabkan oleh $A$. hydrophila merupakan penyakit utama yang menjadi kendala dalam bisnis aquakultur di seluruh dunia (Yu et al., 2004). Ikan yang terinfeksi biasanya memiliki luka pada tubuhnya, bola mata menonjol (exophthamia), terjadi pendarahan pada beberapa bagian tubuh dan perut membuncit. Ikan yang terinfeksi dengan luka terbuka dapat menyebarkan penyakit ini ke ikan lain, dan ikan yang terlihat sehat tetapi membawa penyakit ini (sub clinical carriers) kemungkinan ada dan akan melepaskan bakteri yang terdapat dalam kotoran ke lingkungan perairan (Strohmeyer, 2009).

Spirulina sp. mengandung protein $60 \%$ yang terdiri dari 12 asam amino esensial, 10 vitamin, dan juga sifat terapi seperti pigmen fikosianin yang bersifat antioksidan dan antiinflamatori, polisakarida yang memiliki efek antitumor dan antiviral, dan $\gamma$-asam linoleat (GLA) yang berfungsi dalam penurun 
kolesterol (Desmorieux and Decaen, 2005). Lipopolisakarida (LPS) adalah sebuah molekul besar berupa kompleks antara senyawa lipid dan polisakarida dengan ikatan kovalen. Menurut Boajiang (1994), dalam penelitiannya terhadap tikus mengatakan bahwa polisakarida yang terkandung pada Spirulina plantensis dapat memperbaiki fungsi imunitas seluler nonspesifik dan fungsi humoral spesifik. LPS merangsang makrofag dan sel monositik yang dianggap menyebabkan pelepasan mediator secara cepat, terutama sitokin, interleukin IL-1, IL-6 dan tumor necrosis factor TNF, yang pada akhirnyanya mengaktifkan sel-sel lain yang terlibat dalam mekanisme pertahanan inang (Gallay et al., 1993). Dalam penelitian yang dilakukan oleh Tayag (2010) yaitu pemberian ekstraksi air panas dari Spirulina platesis yang diberikan pada udang dan ditantang dengan Vibrio alginolyticus menunjukkan bahwa Spirulina platensis memiliki pengaruh terhadap beberapa parameter sistem imun udang. Selvaraj et al. (2008) juga membuktikan bahwa pemberian lipopolisakarida memberikan pengaruh yang baik terhadap kelulushidupan serta sistem imun spesifik dan non-spesifik pada ikan Cyprinus carpio yang ditantang dengan Aeromonas hydrophila.

Pemberian imunostimulan untuk ikan dapat dilakukan dengan cara pemberian secara oral, perendaman langsung, dan penyuntikan intraperitonial (Tindal, 1989). Satyantini dkk. (2016) telah melakukan penelitian pemberian ekstrak air panas Spirulina platensis melalui suntik pada ikan gurami, dan hasil penelitian itu menunjukkan bahwa ekstrak air panas Spirulina platensis dapat meningkatkan sistem imun non spesifik yaitu peningkatan leukosit dan aktifitas fagositosis pada ikan gurami.

Dari penjabaran di atas, perlu dilakukan penelitian lebih lanjut mengenai pengaruh pemberian ekstraksi air panas Spirulina platensis dengan cara perendaman terhadap kululushidupan, sistem imun (parameter total leukosit dan aktivitas lisozim) serta histopatologi organ hati ikan Gurami yang diinfeksi dengan Aeromonas hydrophila.

\section{METODE PENELITIAN}

Penelitian dilaksanakan di Institute of Tropical Disease dan Laboratorium Fakultas Perikanan dan Kelautan Universitas Airlangga pada bulan Januari-Juni 2016.

Alat-alat yang digunakan adalah (a) alat ekstraksi; thermometer, gelas ukur, hot plate, timbangan digital, kertas saring, vacum bucner, sentrifus, pipet tetes, micro pipet (b) alat pemeliharaan; akuarium, tandon air, aerator, selang aerasi, batu aerasi, selang sipon, kertas $\mathrm{pH}$ (c) alat kultur bakteri; petri disk, tabung reaksi, pipet, autoclave, inkubator, kulkas, kapas, alumunium foil (d) alat untuk uji total leukosit; haemisitometer, mikroskop, objek glass, pipet tetes (e) alat untuk pembuatan preparat histopatologi; baker glass, objek glass, cover glass, pipet (f) alat untuk uji aktifitas lisozim; micro titer plate ELISA Reader.

Bahan yang digunakan dalam penelitian adalah (a) bahan ekstraksi; Spirulina platensis dan aquades (b) bahan pemeliharaan; ikan Osphronemus gouramy, air, pakan ikan, garam ikan, $\mathrm{KMnSO}_{4}$, formalin (c) bahan kultur bakteri: bakteri Aeromonas hydrophila, media TSA, media TSB (d) bahan untuk uji total leukosit ; anti coagulan, larutan Turk's, es batu (e) bahan untuk pembuatan preparat dan pewarnaan histopatologi; Paraffin, Formalin PA, Etahnol PA, Xylene PA, Haematoxylin Crystal, Mercury Oxide, Hydrochloric Acid, Amonium atau Potassium Ammonium Sulfat, Sodium Phosfat Dibasic, Natrium Chlorida, Entelan, Methanol, Asam Asetat Glacial, Sodium Phosphat Monobasic, Xylene, Alkohol absolute, Alkohol 95\%, HE, Aquadest Acid Alkohol (f) bahan untuk uji aktifitas lisozim; bakteri Micrococcus lysodeikticus, PBS.

Penelitian ini menggunakan metode eksperimental untuk mengetahui pengaruh pemberian ektrak Spirulina terhadap system kekebalan tubuh ikan Osphronemus gouramy yang dinfeksi Aeromonas hydrophila dengan dosis ektrak Spirulina platensis yang berbeda. Perhitungan dosis didapatkan dari 
Jurnal Biosains Pascasarjana Vol. 19 (2017) pp

(C) (2017) Sekolah Pascasarjana Universitas Airlangga, Indonesia

hasil penelitian pendahuluan yang dilakukan

sebelumnya. Hasil terbaik pada penelitian 
sebelumnya dengan cara menginjeksi ekstrak Spirulina platensis dengan dosis 20 ppm (Satyantini dkk., 2016). Dari dosis tersebut, dapat ditentukan dosis perendaman ekstrak Spirulina platensis dengan dikalikan 1.5 dari dosis terbaik pemberian secara penyuntikan berdasarkan Selvaraj (2009), sehingga didapatkan dosis perlakuan perendaman adalah 15 ppm, $30 \mathrm{ppm}$ dan $60 \mathrm{ppm}$. Eksperimental merupakan suatu tindakan yang dibatasi dengan nyata dan dapat dianalisis hasilnya (Kusriningrum, 2008). Perlakuan dari penelitian ini adalah sebagai berikut :

K (-) : Ikan tanpa direndam ekstrak Spirulina platensis tanpa uji tantang (direndam dengan air steril).

$\mathrm{K}(+)$ : Ikan tanpa direndam ekstrak Spirulina platensis lalu diinfeksi Aeromonas hydrophila.

A : Ikan direndam dengan ekstrak Spirulina platensis dengan konsentrasi $15 \mathrm{ppm}$, lalu diinfeksi dengan $A$. hydrophila.

B : Ikan direndam dengan ekstrak Spirulina platensis dengan konsentrasi $30 \mathrm{ppm}$, lalu diinfeksi dengan $A$. hydrophila.

C : Ikan direndam dengan ekstrak Spirulina platensis dengan konsentrasi 60 ppm, lalu diinfeksi dengan $A$. hydrophila.

Perendaman dengan ekstrak air panas S. platensis dilakukan dua kali, yaitu pada hari ke-1 dan hari ke -7. Infeksi A. hydrophila dilakukan pada hari ke-15.

Prosedur dari pemeliharan ikan Osphronemus gouramy dalam penelitian ini adalah dengan menyiapkan alat dan bahan seperti akuarium dan aerasi dengan cara dibersihkan terlebih dahulu, setelah itu akuarium diisi dengan air sebanyak 20 liter dan diberi aerasi untuk media pemeliharaan ikan gurami. Ikan gurami dengan ukuran 7-8 $\mathrm{cm}$ dimasukan ke dalam akuarium sebanyak 15 ekor setiap akuarium, dilakukan perendaman dengan ekstrak Spirulina platensis dengan konsentrasi sesuai perlakuan, setiap perlakuan terdapat 3 kali ulangan dengan penempatan akuarium perlakuan secara acak. Pemberian pakan dilakukan pada pagi dan sore hari. Perendaman dengan ekstrak air panas S. platensis dilakukan dua kali, yaitu pada hari ke-1 dan hari ke - 7 .

Uji tantang dilakukan pada hari ke -15 dengan Aeromonas hydrophila $10^{5} \mathrm{cfu} / \mathrm{mL}$ dengan cara disuntik secara intra peritoneal 0.1 mL/ekor (Setyowati, 2003). Pengamatan kelangsungan hidup ikan gurame dilakukan seriap hari selama penelitian setelah infeksi, sedangkan pengamatan total leukosit, dan aktivitas lisozim pada hari ke-7, 14, dan 25. Pengamatan histopatologi organ hati dilakukan pada akhir penelitian.

Metode ekstraksi air panas Spirulina platensis adalah disusun berdasarkan metode yang dijelaskan Tayag et al., (2010) yaitu 20 gram tepung Spirulina platensis ditambahkan ke $100 \mathrm{ml}$ air deionisasi, lalu dipanaskan di atas hot plate yang diatasnya terdapat air mendidih (dipanaskan di dalam air mendidih tersebut) dan diaduk selama 1 jam dengan suhu $90^{\circ} \mathrm{C}$. Selanjutnya disentrifuse dengan kecepatan $3500 \mathrm{rpm}$ pada suhu $4^{\circ} \mathrm{C}$ selama 15 menit untuk memisahkan endapan dan supernatant. Endapan dan supernatant dipisahkan, jika supernatan belum mencapau $100 \mathrm{ml}$, maka endapan di ekstak kembali dengan menambahan air deionisasi hingga didapatkan supernatan sejumlah $100 \mathrm{ml}$. Supernatan dikeringkan dengan proses freeze drying.

\subsection{Penghitungan Total Leukosit}

Penghitungan total leukosit (Svobodova dan Vyukusova, 1991) dengan cara mengambil darah dengan pipet yang berisi bulir pengaduk warna putih sampai skala 0,5 . Lalu tambahkan larutan Turk's (berfungsi untuk mematikan sel-sel darah merah) sampai skala 11, pengadukan darah di dalam pipet dilakukan dengan mengayunkan tangan yang memegang pipet seperti membentuk angka delapan selama 3 - 5 menit sehingga darah tercampur rata. Setelah itu tetesan pertama larutan darah dalam pipet dibuang, selanjutnya teteskan pada haemacytometer tipe Neubauer kemudian ditutup dengan gelas penutup. Jumlah sel darah putih dengan bantuan mikroskop dengan perbesaran $400 \mathrm{x}$. Jumlah leukosit dihitung 
dengan cara mengkonversikan dengan jumlah sel total kotak besar dan volume kotak sehingga didapat jumlah sel darah putih per $\mathrm{mm}^{3}$

$\sum$ leukosit $=$ rataan $\sum$ sel terhitung $x \frac{1}{\text { volume kotak besar }} x$ pengenceran

\subsection{Aktivitas Lisozim}

Darah diambil dari ikan tanpa anti koagulan, darah disimpan pada suhu ruang selama dua jam, kemudian pada lemari es $\left(4^{\circ} \mathrm{C}\right)$ selama 24 jam. Serum kemudian dipanen dengan cara disentrifugasi pada 5000 rpm (rotation per minute) selama tiga menit. Uji aktivitas lisozim dilakukan dengan metode Lygren et al. (1999) dalam Satyantini (2013) $10 \mu \mathrm{l}$ serum sampel diletakkan ke dalam micro titer plate lalu ditambahkan dengan $190 \mu \mathrm{l}$ suspensi Micrococcus lysodeikticus (SigmaAldrich Chemical) $(0,2 \mathrm{mg}$ Micrococcus lysodeikticus / mL PBS ( $\mathrm{pH}$ 7.4)) digoyang perlahan pada suhu ruang yang konstan. Setelah 1 dan 30 menit inkubasi, selanjutnya dilakukan pembacaan dengan menggunakan micro titer plate ELISA Reader dengan panjang gelombang $\mathrm{nm}$. (Aktifitas lisozim relative (unit) dihitung sbb : 1 Unit $=0,001$ penurunan absorrban/menit. Jika penghitungan aktivitas lisozim mutlak diperlukan, maka dapat menggunakan larutan standar dari putih telur ayam dengan beberapa konsentrasi untuk membuat kurva standar prosedur pengukuran sama).

\subsection{Histopatologi Organ Hati}

Preparat histologis yang dibuat adalah hati ikan. Untuk mempresentasikan keseluruhan organ hati, maka tiap sampel organ hati dibedah menjadi 3 yaitu bagian frontal, median dan distal. Ikan dibedah dan diambil bagian hatinya, diawetkan dengan formalin $4 \%$ selama 24 jam. Setelah itu dilakukan fiksasi, memindahkan hati ke dalam larutan FAA selama 24 jam. Dilanjutkan dengan proses dehidrasi, dilakukan secara bertingkat dengan alkohol 70\%, 80\%, 90\%, 95 $\%$, serta alkohol masing-masing 1 jam.

Clearing, dilakukan selama 1 jam yaitu dimasukkan ke dalam larutan alkoholxilol, lalu memasukkannya ke dalam xilol murni I, II, III 
Jurnal Biosains Pascasarjana Vol. 19 (2017) pp

(C) (2017) Sekolah Pascasarjana Universitas Airlangga, Indonesia

masing-masing selama 20 menit. Setelah

proses cleaning dilakukan infiltrasi

menggunakan paraffin. Hati dimasukkan

kedalam xylol : parafin $(1: 1)$ cair selama 20 menit, kemudian memasukkan parafin cair I, II, III masing-masing selam 20 menit di dalam oven dengan suhu $60^{\circ} \mathrm{C}$. Setelah itu dilakukan embedding, tahapan menanam jaringan atau sampel yang digunakan. Paraffin cair dituangkan ke dalam cetakan sampai penuh kemudian membenamkan potongan organ ke dalam parafin tersebut. Jaringan diletakkan pada posisi dasar tengah dengan posisi melintang. Setelah itu sampel dipotong menggunakan microtome dengan ketebalan 610 mikron, proses ini disebut dengan sectioning. Dilanjutkan dengan affixing, perekatan dengan menggunakan albumin dan gliserin dengan perbandingan 1:1, disimpan dalam kotak sediaan selama 1 hari, untuk menghilangkan parafin, sediaan dimasukkan ke dalam xylol selama 10 menit (deparafinisasi).

Langkah selanjutnya adalah staining atau pewarnaan, proses pewarnaan dengan menggunakan hematoxylin dan eosin dengan langkah sediaan histologis dihisap xylolnya dengan menggunakan kertas saring. Kemudian berturut-turut dimasukkan ke alkohol 96\%, $90 \%, 80 \%, 70 \%, 60 \%, 50 \%, 40 \%$ dan $30 \%$ masing masing selama 5 menit lalu ke aquades selama 5 menit. Dicuci dengan air mengalir kurang lebih 2 menit, dimasukkan ke dalam haemotoxylin selama 4 menit, lalu dicuci dengan air mengalir selama 10 menit, dimasukkan ke dalam aquades dan alkohol $50 \%, 60 \%, 70 \%, 80 \%, 90 \%$, 96\% masingmasing beberapa celupan, lalu dimasukkan ke dalam eosin selama 1,5 menit, dimasukkan ke dalam alkohol $70 \%, 80 \%, 90 \%$, 95\%, lalu preparat dikering-anginkan dan dimasukkan ke xylol selama 15 menit, sediaan histologi ditetesi dengan canada balsam lalu ditutup dengan cover glass. Terakhir adalah mounting (penutupan) dan labelling (pemberian label) yaitu Penutupan preparat dengan menggunakan kaca penutup dan memberi identitas pada preparat. Pengamatan di Laboratorium Pengamatan preparat dilakukan mengguankan mikroskop compound dengan perbesaran 40-1000x. Penilaian kerusakan hati 
ikan gurami dinilai berdasarkan Histological Activity Index (HAI) Knodell et al., (1981).

Tabel 1. Penilaian kerusakan hati ikan berdasarkan Histological Activity Index (HAI) (Knodell et al., 1981)

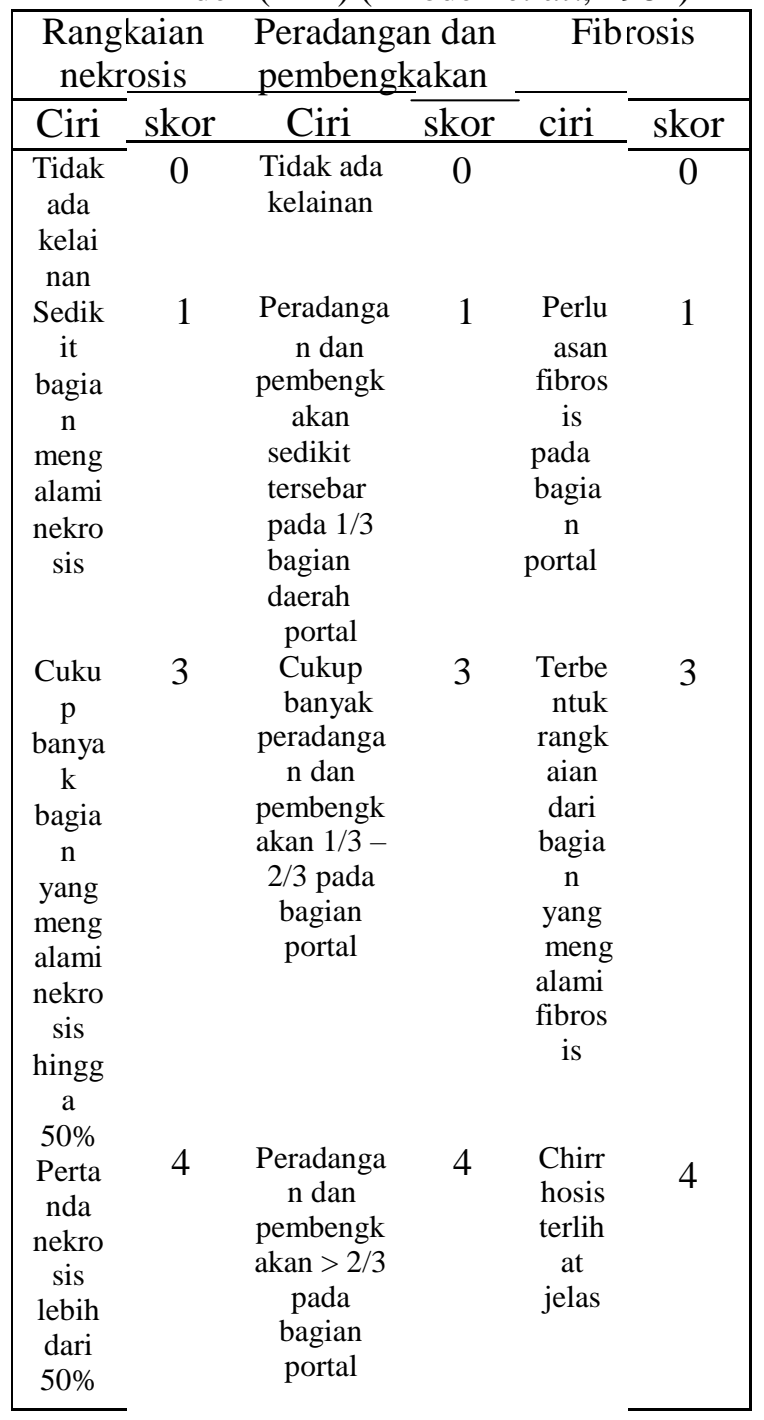

\subsection{Survival Rate (SR)}

Kelulus hidupan (Survival Rate) ikan Gurami dihitung dengan cara:

$\mathrm{SR}=\mathrm{Nt} / \mathrm{No} \times 100 \%$

Keterangan :

$\mathrm{SR}=$ Sintasan $/$ Survival Rate $(\%)$

$\mathrm{Nt}=$ jumlah total ikan yang hidup pada akhir penelitian (ekor)

No $=$ jumlah total ikan pada awal penelitian (ekor)

\section{HASIL DAN PEMBAHASAN}

\subsection{Hasil}

Total leukosit ikan Gurami yang direndam ekstrak air panas Spirulina platensis dengan dosis yang berbeda menunjukkan hasil yang berbeda nyata antar perlakuan $(\mathrm{P}<0.05)$. Kisaran nilai total leukosit pada penelitian ini adalah $18 \times 10^{4}-68 \times 10^{4} \mathrm{sel} / \mathrm{mm}^{3}$. Pada Gambar 1 menunjukkan total leukosit ikan gurami dengan perendaman ekstrak air panas Spirulina platensis dengan konsentrasi 30 ppm menunjukkan hasil tertinggi, yaitu $62 \times 10^{4}$ $\mathrm{sel} / \mathrm{mm}^{3}$ pada hari ke $7,68 \times 10^{4} \mathrm{sel} / \mathrm{mm}^{3}$ pada hari ke 14, dan 10 hari setelah diinfeksi A. hydrophila (hari ke-25) $42 \times 10^{4} \mathrm{sel} / \mathrm{mm}^{3}$. Total leukosit hari ke- 7, 14, 25 perlakuan $\mathrm{K}(+)$ menunjukkan nilai terendah yaitu $18 \mathrm{x}$ $10^{4} \mathrm{sel} / \mathrm{mm}^{3}, 18 \times 10^{4} \mathrm{sel} / \mathrm{mm}^{3}$, dan $8,6 \times 10^{4}$ $\mathrm{sel} / \mathrm{mm}^{3}$.

Pada gambar 2 menunjukkan aktivitas lisozim ikan gurami pada hari ke-7 dan ke-14 perendaman ekstrak Spirulina platensis dengan dosis 30 ppm merupakan hasil terbaik, akan tetapi tidak berbeda nyata dengan perendaman dengan konsentrasi 15 ppm maupun $60 \mathrm{ppm}$, sedangkan ikan tanpa perendaman ekstrak Spirulina platensis (K+ dan K-) memiliki aktivitas lisozim yang berbeda lebih rendah $(\mathrm{P}<0.05)$. Setelah dilakukan uji tantang pada ikan gurami, aktivitas lisozim pada hari ke-25 perlakuan B (perendaman ekstrak $30 \mathrm{ppm}$ ) merupakan hasil terbaik, sedangkan hasil terendah didapatkan dari perlakuan $\mathrm{K}(+)$. 
Jurnal Biosains Pascasarjana Vol. 19 (2017) pp

(C) (2017) Sekolah Pascasarjana Universitas Airlangga, Indonesia
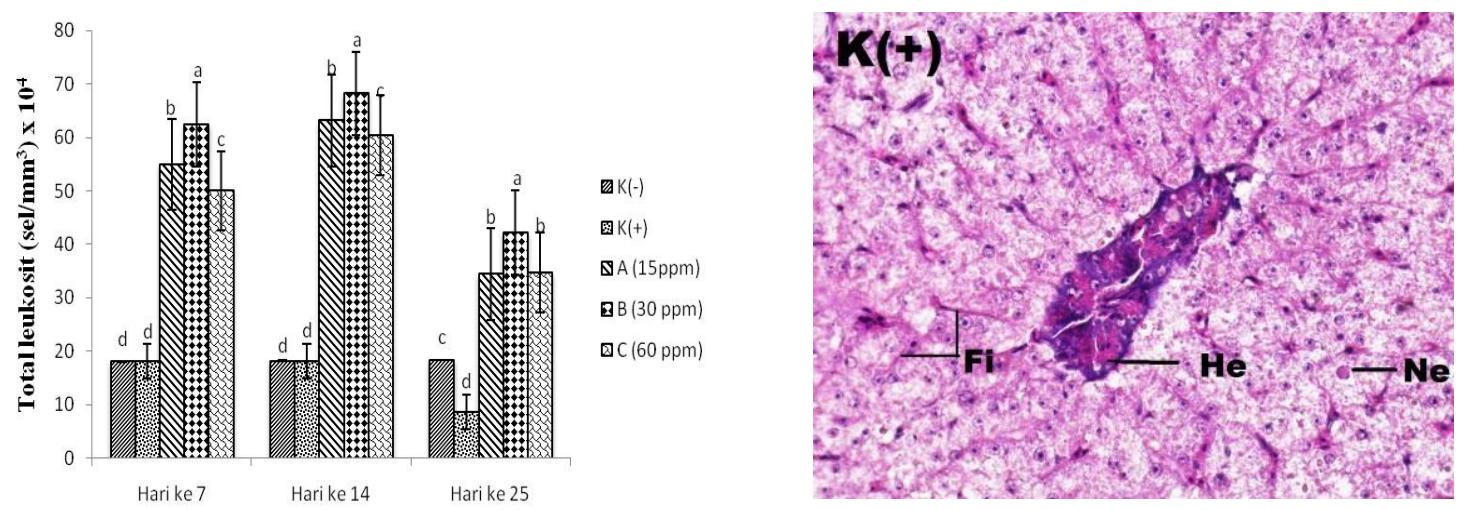

Gambar 1. Total leukosit ikan gurami yang direndam ekstrak air panas Spirulina platensis dengan konsentrasi yang berbeda

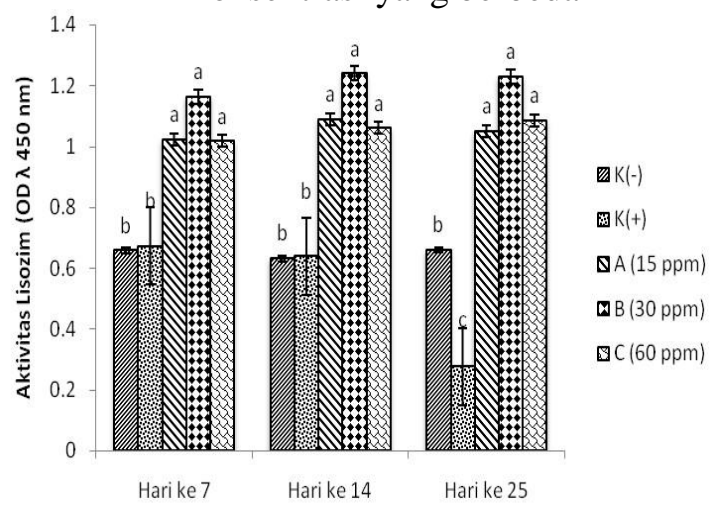

Gambar 2. Aktivitas lisozim ikan gurami yang direndam ekstrak air panas Spirulina platensis dengan konsentrasi yang berbeda
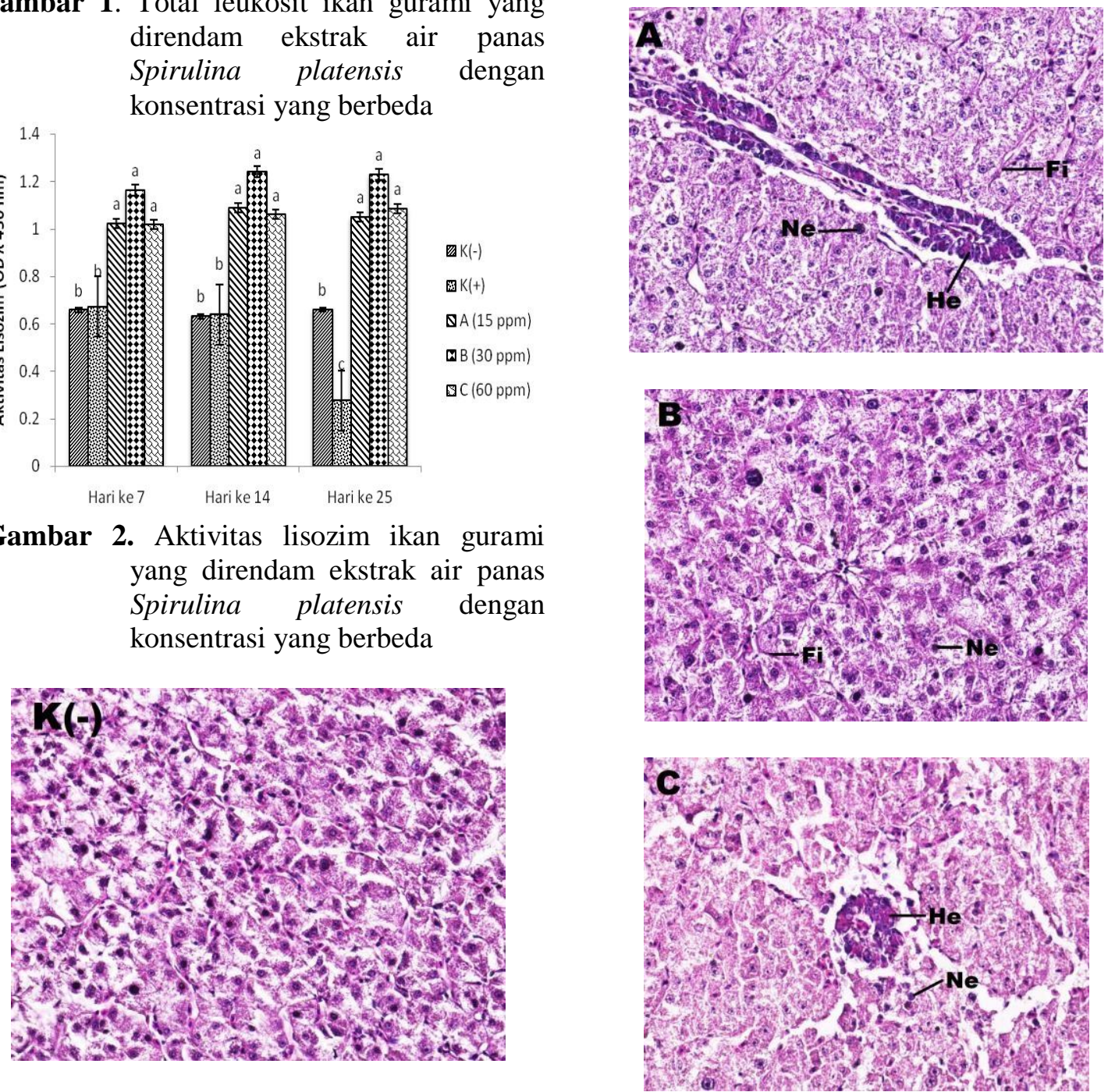

Gambar 3. Histopatologi hati pada perlakuan $\mathrm{K}(-), \mathrm{K}(+), \mathrm{A}, \mathrm{B}$ dan $\mathrm{C}$. $(\mathrm{He}=$ Hemorage ; $\mathrm{Ne}=$ Necrosis $; \mathrm{Fi}=$ Fibrosis) 
Tabel 3. Skoring kerusakan hati ikan gurami yang direndam ekstrak air panas Spirulina platensis dengan konsentrasi yang berbeda

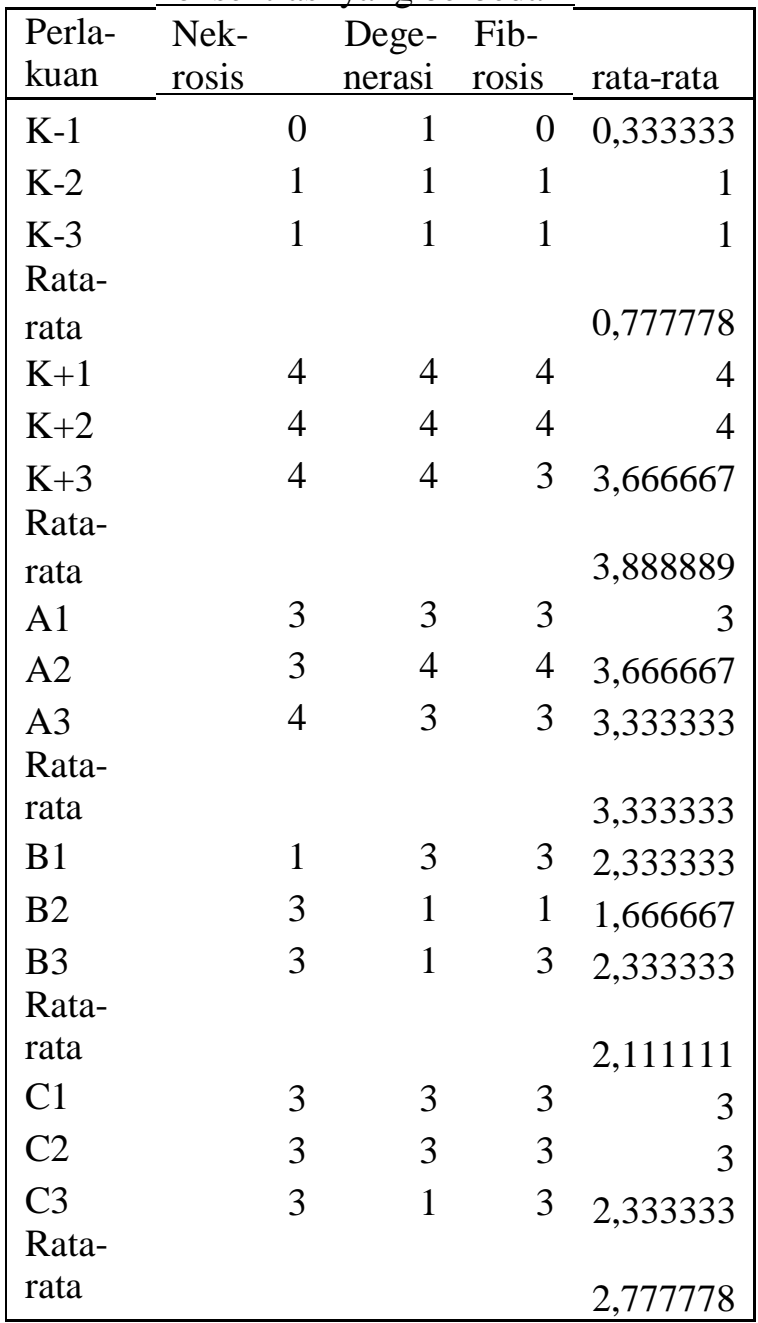

Keterangan : $\mathrm{K}(-)=$ tanpa perendaman ekstrak S.platensis dan tanpa diuji tantang, $\mathrm{K}(+)=$ tanpa perendaman ekstrak S.platensis lalu diinfeksi A. hydrophila pada hari ke-15, A = perendaman ekstrak S.platensis konsentrasi 15 ppm pada hari ke-1 dan hari ke-7 dan diinfeksi pada hari ke-15, B $=$ perendaman ekstrak S.platensis konsentrasi 30 ppm pada hari ke-1 dan hari ke-7 dan diinfeksi pada hari ke-15, $\mathrm{C}=$ perendaman ekstrak S.platensis konsentrasi 60 ppm pada hari ke-1 dan hari ke-7 dan diinfeksi pada hari ke-15.

Pengamatan kerusakan pada organ hati dilakukan pada hari terakhir penelitian (hari ke-25). Perlakuan K(-) hati ikan hampir tidak mengalami kerusakan pada sel, pada perlakuan
$\mathrm{K}(+)$ hati ikan mengalami kerusakan yang paling besar dengan terjadi hemoragi, 
Jurnal Biosains Pascasarjana Vol. 19 (2017) pp

(C) (2017) Sekolah Pascasarjana Universitas Airlangga, Indonesia

nekrosis, dan fibrosis. Pada perlakuan A, B, dan $\mathrm{C}$ juga mengalami kerusakan sel nekrosis, hemoragi, dan fibrosis akan tetapi tidak sebanyak kerusakan pada perlakuan $\mathrm{K}(+)$. Skor kerusakan hati tertinggi didapatkan dari perlakuan $\mathrm{K}(+)$, sedangkan skor kerusakan hati terendah (terbaik) diperoleh dari perlakuan K(), lalu disusul dengan perlakuan B (perendaman ekstrak Spirulina platensis konsentrasi $30 \mathrm{ppm}$ ).

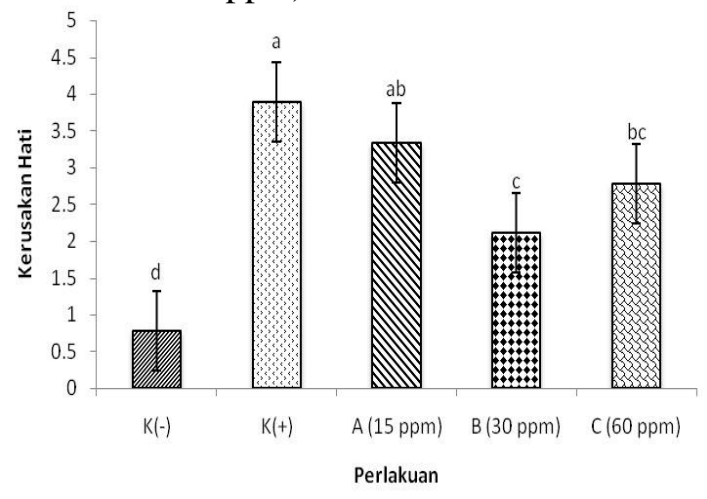

Gambar 4. Skoring kerusakan hati ikan gurami yang direndam ekstrak air panas Spirulina platensis dengan konsentrasi yang berbeda

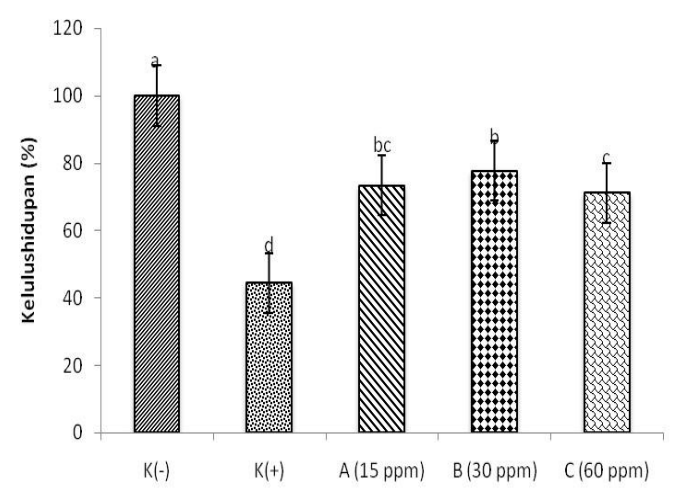

Gambar 5. Kelulus hidupan ikan gurami terhadap A. hydrophila setelah pemberian ekstrak air panas Spirulina platensis dengan konsentrasi yang berbeda

Kelulushidupan ikan gurami pada penelitian ini didapatkan hasil yang berbeda nyata tiap perlakuan $(\mathrm{P}<0.05)$. Kelulushidupan tertinggi diperoleh dari perlakuan $\mathrm{K}(-)$, lalu disusul dengan perlakuan B (SR 77\%), 
kemudian perlakuan A (SR 73\%), perlakuan C (SR 71\%), sedangkan perlakuan $\mathrm{K}(+)$ merupakan nilai kelulushidupan terendah dengan nilai SR $44 \%$.

Kualitas air pada penelitian ini dipantau selama penelitian berlangsung, karena kualitas air pada bak pemeliharaan ikan gurami merupakan factor penting dalam keberhasilan pemeliharaan ikan. Rata-rata hasil pemeriksaan kualitas air selama penelitian terdapat pada Tabel 3.

Tabel 3. Hasil rata-rata pemerikasaan kualitas air selama pemeliharaan ikan gurami

\begin{tabular}{|c|c|c|c|c|c|}
\hline \multirow{2}{*}{$\begin{array}{c}\text { Parameter } \\
\text { Kualitas } \\
\text { Air }\end{array}$} & \multicolumn{5}{|c|}{$\begin{array}{c}\text { Rata -rata kualitas air selma } \\
\text { p emeliharaan } 25 \text { hari }\end{array}$} \\
\hline & $\mathrm{K}(-)$ & $\mathrm{K}(+)$ & A & B & $\mathrm{C}$ \\
\hline Suhu $\left({ }^{\circ} \mathrm{C}\right)$ & 28 & 28,5 & 28 & 28 & 28 \\
\hline $\mathrm{pH}$ & 7,4 & 7,5 & 7,3 & 7,3 & 7.4 \\
\hline $\begin{array}{l}\text { Amoniak } \\
(\mathrm{mg} / \mathrm{l})\end{array}$ & 0,52 & 0,5 & 0,5 & 0,52 & 0,52 \\
\hline $\begin{array}{l}\mathrm{DO} \\
(\mathrm{mg} / \mathrm{l})\end{array}$ & 5,33 & 5,28 & 5,41 & 5,39 & 5,04 \\
\hline
\end{tabular}

Keterangan : $\mathrm{K}(-)=$ tanpa perendaman ekstrak S.platensis dan tanpa diuji tantang, $\mathrm{K}(+)=$ tanpa perendaman ekstrak S.platensis lalu diinfeksi A. hydrophila pada hari ke-15, A = perendaman ekstrak S.platensis konsentrasi 15 ppm pada hari ke-1 dan hari ke-7 dan diinfeksi pada hari ke-15, B $=$ perendaman ekstrak S.platensis konsentrasi 30 ppm pada hari ke-1 dan hari ke-7 dan diinfeksi pada hari ke-15, $\mathrm{C}=$ perendaman ekstrak S.platensis konsentrasi 60 ppm pada hari ke-1 dan hari ke-7 dan diinfeksi pada hari ke-15.

\subsection{Pembahasan}

Spirulina platensis mengandung lipopolisakarida yang memiliki efek antitumor dan antiviral (Desmorieux and Decaen, 2005). Lipopolisakarida (LPS) adalah sebuah molekul besar berupa kompleks antara senyawa lipid dan polisakarida dengan ikatan kovalen. Ekstraksi Spirulina platensis dengan menggunakan air panas dapat menghasilkan LPS sebesar 7\% (Chaiklahan et al., 2013).

Perendaman ekstrak air panas Spirulina platensis pada hari ke-1 dan ke-7 dengan konsentrasi 15 ppm, 30 ppm, 60 ppm memberikan pengaruh peningkatan total leukosit lebih baik pada ikan gurami dibanding tanpa perendaman ekstrak Spirulina platensis sampai hari ke-14. Setelah diinfeksi 
Jurnal Biosains Pascasarjana Vol. 19 (2017) pp

(C) (2017) Sekolah Pascasarjana Universitas Airlangga, Indonesia

Aeromonas hydrophila pada hari ke-15, total

leukosit gurami pada hari ke-25 dengan

perendaman ekstrak S.platensis mengalami

penurunan, tetapi ikan gurami dengan

perendaman ekstrak S.platensis tetap menunjukkan nilai yang lebih tinggi dibanding kontrol $(\mathrm{p}<0.5)$. Nilai terendah terletak pada perlakuan $\mathrm{K}(+)$ dengan nilai total leukosit 8,62 X $10^{4} \mathrm{sel} / \mathrm{mm}^{3}$. Minaka (2012) dalam penelitiannya mengungkapkan bahwa leukosit ikan gurami yang terserang Aeromonas hydrophila akan mengalami penurunan jumlah total leukosit. Ikan gurami dengan perendaman ekstrak Spirulina platensis memiliki nilai leukosit yang lebih tinggi setelah diuji tantang karena memiliki total leukosit yang lebih tinggi sebelumnya sebagai bentuk sistem pertahanan awal ikan. Hal ini sejalan dengan hasil penelitian Satyantini (2013) yang mengungkapkan nilai leukosit ikan kerapu bebek setelah diuji tantang dengan dengan Vibrio alginolyticus yang sebelumnya diberi pakan dengan penambahan fikosianin sebagai imunostimulan memiliki nilai total leukosit lebih tinggi dibanding dengan ikan yang hanya diuji tantang dengan V.alginolyticus tanpa pemberian fikosianin terlebih dahulu.

Nilai total leukosit ikan gurami yang meningkat setelah perendaman ekstrak Spirulina platensis dikarenakan LPS S.platensis yang masuk ke dalam tubuh ikan akan berikatan dengan LBP (Lypopolysccharide Binding Protein) dan akan mengaktifasi molekul CD14 pada permukaan sel. Ikatan antara LBP dan CD14 menginduksi TLR-4 yang terdapat pada permukaan sel leukosit (yaitu neutrofil, monosit, dan makrofag) dan akan membentuk ikatan kompleks dengan protein kecil yang disebut MD-2 (Myeloid Differentiation factor 2) (Wang and Quinn, 2010). LPS yang terkandung dalam Spirulina platensis merangsang makrofag dan sel monosit yang menyebabkan pelepasan mediator secara cepat sehingga dapat mempercepat poliferasi sel imun (Gallay et al., 1993).

Nilai total leukosit ikan gurami yang meningkat setelah perendaman ekstrak Spirulina platensis menunjukkan bahwa sistem imunitas ikan tersebut meningkat, sehingga disaat ikan diinfeksi dengan A.hydrophila ikan 
tersebut mampu memberikan pertahanan tubuh dibanding ikan gurami tanpa perendaman ekstrak S.platensis. Leukosit ikan merupakan bagian dari sistem pertahanan tubuh yang bersifat non-spesifik (Moyle and Cech, 1988).

Perendaman ekstrak Spirulina platensis pada ikan gurami juga meningkatkan aktivitas lisozim. Aktifitas lisozim pada penelitian ini menunjukkan bahwa ikan yang diberi imunostimulan Spirulina platensis memiliki aktivitas lisozim yang lebih baik dibanding aktivitas lisozim ikan tanpa perendaman ekstrak Spirulina platensis. Konsentrasi perendaman ekstrak S.platensis $(15,30$, dan $60 \mathrm{ppm})$ sama-sama memberikan pengaruh terbaik dalam meningkatkan aktivitas lisozim dan memberikan pengaruh dengan perbedaan yang nyata dibanding aktivitas lisozim pada ikan kontrol. Hal ini terjadi baik sebelum ataupun setelah dilakukan infeksi dengan Aeromonas hydrophila. Pada penelitian sebelumnya, pemberian ekstrak air panas Spirulina platensis dengan cara penyuntikan maupun perendaman pada udang vanammei dapat meningkatkan aktivitas lisozim baik sebelum maupun setelah dilakukan uji tantang dengan Vibrio alginolyticus (Tayag, 2010). Misra et al. (2006) juga menjabarkan dari hasil penelitiannya bahwa ikan Labeo rohita yang diberi immunostimulan $\beta$-glucan lalu ditantang dengan bakteri Aeromonas hydrophila dan Edwardsiella tarda memiliki aktivitas lysozim yang lebih tinggi dibanding ikan tanpa pemberian immunostimulan.

Aktivitas lisozim pada ikan gurami diukur menggunakan microtitter plate ELISA reader dengan OD $\lambda 450 \mathrm{~nm}$ dengan inkubasi menggunakan bakteri Gram positif Micrococcus lysodeikticus. Lisozim adalah enzim yang mempunyai daya bakterisid yang banyak terdapat pada monosit dan neutrofil. LPS yang terkandung dalam ekstrak air panas Spirulina platensis yang masuk ke dalam tubuh ikan melalui perendaman dapat merangsang TLR4 yang terdapat pada permukaan sel yaitu monosit, makrofag dan neutrofil sehingga mempercepat poliferasi sel imun tersebut, disaat hal itu terjadi, organellaorganella intraseluler pada monosit dan neutrofil juga akan bertambah yang dimana salah satunya adalah enzim lisozim (Wang and Quinn, 2010, Bellanti et al., 1985). Masuknya immunostimulan akan merangsang sel fagosit untuk memproduksi lebih banyak lisozim (Yin, et al., 2009). Peningkatan aktivitas lisozim juga berkorelasi dengan aktivitas fagositosis, semakin tinggi nilai aktivitas lisozim maka semakin tinggi pula kemampua sel dalam melakukan aktivitas fagositosis (Yin, et al., 2009 ).

Kerusakan hati pada ikan gurami memiliki perbedaan kerusakan tiap perlakuan, pada perlakuan $\mathrm{K}(-)$ hati ikan gurami hampir tidak ditemui kerusakan pada sel, sedangkan kerusakan terbesar terjadi pada perlakuan $\mathrm{K}(+)$. Hal ini disebabkan karena pada ikan $\mathrm{K}(+)$ tidak diberikan immunostimulan terlebih dahulu sebelum diinfeksi A.hydrophila, sehingga saat tubuh ikan terinfeksi patogen ikan belum memiliki sistem pertahanan tubuh yang lebih baik. Patogen yang masuk seperti Aeromonas hydrophila memproduksi toksin, terdapatnya zat toksik dalam tubuh ikan dapat mempengaruhi struktur histopatologi hati ikan sehingga dapat mengakibatkan kelainan histopatologi hati yaitu pembengkakan sel, nekrosis atau kematian sel, fibrosis dan serosis (Nabib dan Pasaribu, 1989).

Pada ikan gurami yang diberi immunostimulan Spirulina platensis sebelum diuji tantang Aeromonas hydrophila mengalami kerusakan hati yang lebih sedikit dibanding perlakuan $\mathrm{K}(+)$. Hal ini dikarenakan pemberian imunostimulan LPS Spirulina platensis dapat meningkatkan sel fagosit (Gallay et al., 1993), sel kupffer adalah jenis makrofag sinusoid hati yang memiliki fungsi untuk memfagosit patogen yang masuk ke dalam hati (Thomson and Knolle, 2010), sehingga disaat ikan gurami terinfeksi A.hydrophila sel kupffer bisa menfagosit patogen lebih baik agar tidak terjadi kerusakan sel pada hati.

Pada penelitian Astiatih (2013) juga menunjukkan hati ikan lele yang diinfeksi Aeromonas hydrophila dengan injeksi $10^{7}$ $\mathrm{cfu} / \mathrm{ml}$ mengalami kerusakan hati berupa nekrosis, hemoragi dan edema pada hari ke-5 setelah infeksi. Pada penelitian Tanjung $d k k$ (2010) menunjukkan hati ikan gurami yang terserang bakteri Aeromonas hydrophila 
mengalami kerusakan sel seperti nekrosis dan hemoragi.

Kematian yang terjadi selama 10 hari pemeliharaan setelah dilakukan uji tantang Aeromonas hydrophila pada penelitian ini adalah $42 \%$ pada perlakuan $\mathrm{K}(+)$, pada ikan dengan pemberian immunostimulan terlebih dahulu sebelum diinfeksi bakteri (perlakuan A, B, dan C) terjadi kematian sebanyak 26, 23, dan 29\% masing-masing. Sementara perlakuan $\mathrm{K}(-)$ yaitu tanpa pemberian imunostimulan dan infeksi bakteri mengalami kelulushidupan $100 \%$. Ikan gurami dengan pemberian imunostimulan LPS Spirulina platensis memiliki kelulushidupan yang lebih baik dibanding ikan tanpa pemberian imunostimulan, hal ini terjadi karena imunostimulan dapat meningkatkan sistem imun pada ikan gurami sehingga ikan gurami lebih resisten terhadap Aeromonas hydrophila. Pada penelitian Misra et al (2006) menunjukkan bahwa pada ikan Labeo rohita yang diberi immunostimulan lalu ditantang Aeromonas hydrophila mengalami mortality sebesar $20-35 \%$, yakni lebih rendah dari $\mathrm{K}(+)$ yang mengalami mortality sebesar $60 \%$. Penelitian Tayag dkk (2010) menyimpulkan bahwa dengan konsentrasi Aeromonas hydrophila $10^{8} \mathrm{cfu} / \mathrm{ml}$ mampu mengakibatkan kematian ikan gurami minimal tiga hari setelah terinfeksi.

Kualitas air pada penelitian dengan ketinggian air $40 \mathrm{~cm}$ di masing-masing akuarium, terukur suhu air berkisar antara 28$28,5^{\circ} \mathrm{C}, \mathrm{pH}$ berkisar antara 7,3-7,5, Amonia berkisar antara $0,5-0,52 \mathrm{mg} / \mathrm{l}$, sedangkan oksigen terlarut berkisar antara 5,04 - 5,41 $\mathrm{mg} / \mathrm{L}$. Hal ini sesuai dengan SNI ikan gurami (2000) bahwa untuk pemeliharan ikan gurami dengan ukuran $\pm 8 \mathrm{~cm}$ ketinggian air yang baik adalah $40-60 \mathrm{~cm}$, suhu $25-30{ }^{\circ} \mathrm{C}, \mathrm{pH}$ 6.5-8.5.

\section{KESIMPULAN DAN SARAN \\ 5.1 Kesimpulan}

1) Perendaman ekstrak air panas Spirulina platensis pada ikan gurami (Osphronemus gouramy) dapat meningkatkan total leukosit setelah diinfeksi A.hydrophila.

2) Perendaman ekstrak air panas Spirulina platensis pada ikan gurami (Osphronemus gouramy) dapat meningkatkan aktivitas lisozim setelah diinfeksi A.hydrophila.

3) Perendaman ekstrak air panas Spirulina platensis pada ikan gurami (Osphronemus gouramy) dapat menurunkan kerusakan organ hati setelah diinfeksi A.hydrophila.

4) Perendaman ekstrak air panas Spirulina platensis pada ikan gurami (Osphronemus gouramy) dapat meningkatkan kelulus hidupan setelah diinfeksi A.hydrophila.

\subsection{Saran}

Dari penelitian ini, disarankan untuk dilakukan penelitian lebih lanjut mengenai pemberian ekstrak air panas Spirulina platensis dalam bentuk pemberian melalui pakan agar mudah diterapkan dalam budidaya untuk meningkatkan resistensi ikan gurami (Osphronemus gouramy) terhadap Aeromonas hydrophila.

\section{UCAPAN TERIMA KASIH}

1. Sekolah Pascasarjana Universitas Airlangga yang telah memberi penulis kesempatan untuk menempuh pendidikan S2 Bioteknologi Perikanan dan Kelautan.

2. Dr.Woro Hastuti Satyantini Ir.,M.Si sebagai pembimbing ketua danProf. Dr. Sri Subekti, drh., DEA.sebagai pembimbing kedua yang denganpenuh perhatian telah memberikan bimbingan, dorongan,dan saran dalampenyusunan usulan penelitian hingga selesainya penyusunan Tesis ini.

3. Prof. Dr. Hari Suprapto, Ir., M.Agr., Dr. Gunanti Mahasri, Ir., M.Si., danRahayu Kusdarwati, Ir., M.Kesselaku dosen penguji yang telah memberikan masukan dan saran dengan penuh kesabaran.

4. Terima kasih tak terhingga juga penulis sampaikan kepada suami Muhammad Khoirul Afif, orang tua, keluarga besar yang telahmemberikan doa restu, kasih saying, motivasi, semangat, dan perhatian selama penyusunan tesis ini. 
5. Fakultas Perikanan dan Kelautan Universitas Airlangga yang menyediakan tempat untukpenelitian.

\section{DAFTAR PUSTAKA}

AOAC. 1998. Official Methods of Analysis of AOAC Internasional, $16^{\text {th }}$ edition. Association Of Official Analytical Chemists. Rockville. USA

Austin, B. And D. A. Austin. 2007. Bacterial Fish Pathogens Diseases in Farmed and Wild Fish. Books In Aquatic and Marine Sciences, Chichester UK Germany.

Asniatih, M. Idris dan S. Kadir. 2013. Studi Histopatologi pada Ikan Lele Dumbo (Clarias gariepinus) yang Terinfeksi Bakteri Aeromonas hydrophila. Jurnal Mina Laut Indonesia. $03: 13-21$.

Boajiang, G. 1994. Study on Effect and Mechanism of Polyccharida of Spirulina platensis on Body Immune Function Improvement. Book of Abstract. Second Asia Pacific Conference on Algal Biotechnology. p.24.

Brenden, R.A. and H.W. Huizinga. 1986. Susceptibility of Normal and X-ray Irradiated Animal to Aeromonas hydrophila Infections. Current Microbiol. 13 : 129-132.

Desmorieux, H. and Decaen, N. 2005. Convective Drying of Spirulina in Thin Layer. Jurnal of Food Engineering, 66: 497-503.

Gallay, P., Heumann, D., Roy, D.L., Barras, C. and Glauser, M.P. 1993. Lippopolysaccharide-binding protein as a major plasma protein responsible for endotoxemie shock. Proceedings of the National Academy of Sciences (USA) 90: 9935-9938.
Janda, J.M. 1991. Recent Advances in the Study of the Taxonomy, Pathogenicity, and Infectious Syndrome Associated with the Genus Aeromonas. Clin Microb. Rev., 4: 397.

Kementerian Kelautan dan Perikanan. 2015. Statistik Jumlah Produksi Perikanan Budidaya Kolam Menurut Jenis Ikan dan Provinsi, 2010-2015. http://statistik.kkp.go.id/index.php/stat istik/c/12/0/0/0/0/Statistik-

PerikananBudidayaKolam/?pulau_id= \&subentitas_id=61\&view_data $=1 \&$ tah un_start $=2010 \&$ tahun_to $=2015 \&$ tahu $\mathrm{n}=2015$ \&filter $=$ Lihat + Data $+\% C 2 \% B$ B. 15 november 2015 .

Kementerian Kelautan dan Perikanan. 2015. Statistik Nilai Produksi Perikanan Budidaya Kolam Menurut Jenis Ikan dan Provinsi, 2010-2015. http://statistik.kkp.go.id/index.php/stat istik/c/12/0/0/0/0/Statistik-

PerikananBudidayaKolam/?pulau_id= \&subentitas_id=62\&view_data $=1 \&$ tah un_start $=2010 \&$ tahun_to $=2015 \& \operatorname{tahu}$ $\mathrm{n}=2015 \&$ filter $=$ Lihat + Data $+\% C 2 \% B$ B. 15 november 2015 .

Kusriningrum. 2008. Rancangan Percobaan. Surabaya: Pusat Penerbitan dan Percetakan Unair (AUP), hlm 6-37.

Misra, C.K., Das, B.K., Mukherjee, S.C., Pattnaik, P. 2006. Effect of multiple injections of $\beta$-glucan on non-specific immune response and disease resistance in Labeo rohita fingerlings. Fish and Shellfish Immunol. 20: 305319.

Moyle, P. B. and J. J. Cech. 1988. Fishes. An Introduction to Ichthyology. Second Edition. New Jersey: Prentice Hall. pp 62.

Nabib, R. dan Pasaribu, F. H. 1989. Patologi dan penyakit ikan. Pusat Antar Universitas. Bogor: Institut Pertanian Bogor. 
Rahmaningsih, S. 2012. Pengaruh Ekstrak Sidawayah dengan Konsentrasi yang Berbeda untuk Mengatasi Infeksi Bakteri Aeromonas hydrophyla pada Ikan Nila (Oreochromis niloticus). Jurnal Ilmu Perikanan dan Sumberdaya Perairan.

Satyantini, W. H. 2013. Peningkatan Respon Pertumbuhan, Imun Non Spesifik dan Resistensi Juvenil Ikan Kerapu Bebek (Cromileptes altivelis) dengan Pemberian Fikosianin Spirulina. Disertasi, Institut Pertanian Bogor, Bogor.

Satyantini, W.H., Agustono, Arinbi., E.K Sabdoningrum., M. Budi., L.W. Asmi. 2016. Peningkatan Respons Imun Non Spesifik Ikan Gurame Pasca Pemberian Ekstrak Air Panas Mikroalga Spirulina platensis. Jurnal Kedokteran Hewan Indonesia. 17 (3) : 347-354.

Selvaraj V., Sampath. K., Sekar Vaithilingam. 2008 Administration of lipopolysaccharide increases specific and non-specific immune parameters and survival in carp (Cyprinus carpio) infected with Aeromonas hydrophila. Aquaculture 286 : 176-183.

Setyowati, E. A., 2003. Potensi Spirulina platensis Sebagai Imunostimulan Pada Ikan Gurami (Osphorenemus gouramy Lac.). Tesis. Institut Pertanian Bogor, Bogor.

Standart Nasional Indonesia. SNI : 01-6485.32000. Produksi benih ikan gurame (Osphronemus goramy Lac.) kelas benih sebar.

Svobodova, Z., Vyukusova, B. 1991. Diagnostik, Prevention and Therapy of Fish Disease and Intoxication. Research Institute of fish Culture and Hydrobiology Vodnany
Czechoslovakia.

http//www.fao.org/fi/website/firetrivea ction.do?dom=topic \&fid=16064\&la ng=en. 22 juni 2015 .

Tanjung, L. R., dll. 2011. Uji KetahananBeberapa Strain Ikan Gurami Terhadap Penyakit Aeromonas. Limnotek (2011) 18 (1) : 58-71.

Tayag, C.M., Lin, Y.C., Li, C. C., Liou, C. H., Chen, J. C. 2010. Administration of the hot-water extract of Spirulina platensis enhanced the immune response of white shrimp Litopenaeus vannamei and its resistance against Vibrio alginolyticus. Fish and Shellfish Immunology 28 (2010) 764773.

Thomson, A.W, Knolle, P.A. 2010. Antigenpresenting cell function in the tolerogenic liver environment. Nat Rev Immunol. 10:753-766.

Tindall, B. 1989. Fish Pathology. Edited : Ronald J. Robert.The techniques of immunization. Hal.151.

Wang, X. and Quinn, P.J. 2010. Endotoxins : Lipopolysaccharides og Gram-negatif Bacteria. Subcell Biochem 53: 2-36.

Yin, Guojun., L.Ardo, K.D. Thompson, A. Adams, Z. Jeney, G. Jeney. 2009. Chinese herbs (Astragalus radix and Ganoderma lucidum) enhance immune response of carp, Cyprinus carpio, and protection against Aeromonas hydrophila. Fish and Shellfish Immunol 26 : 140-145.

Yu, H. B., Srinivasa Rao, P. S., Lee, H. C., Vilches, S., Merino, S., Tomas, J. M., and Leung, K. Y. 2004. A Type III secretion System Is Required for Aeromonas hydrophila AH-1 Pathogenesis. Infect. Immun. 72 (3) : 1248-1256. 